\title{
Social responsibility and community development: Lessons from the Sistema de Aprendizaje Tutorial in Honduras
}

\author{
Catherine A. Honeyman ${ }^{\dagger, *}$ \\ Harvard College Social Studies Department, University of Wisconsin - Madison, 3142 View Rd., Madison, WI, 53711, United States
}

\section{A R T I C L E I N F O}

\section{Keywords:}

International education

Comparative education

Development

Curriculum

Social capital

Social responsibility

\begin{abstract}
A B S T R A C T
This article extends understanding of the connections between education, social capital, and development through a mixed-methods case study of the Sistema de Aprendizaje Tutorial, or SAT ${ }^{1}$, an innovative secondary-level education system. The quantitative dimension of the research used survey measures of social responsibility to compare 93 SAT students to 88 other students in conventional Honduran schools, with samples based on the naturally occurring (non-random) presence of one of these two different educational programs in each of nine nearby Honduran communities. Preliminary findings suggest that students in the SAT program held a greater sense of social responsibility than their peers in conventional schools. Students' statements about their own educational experiences were analyzed in order to identify some of the characteristics of the SAT program that may have led to this difference. The SAT approach to developing social responsibility is contrasted to a human rights focused approach.
\end{abstract}

(c) 2010 Elsevier Ltd. All rights reserved.

\section{Introduction}

Sitting behind a worn wooden desk in a rural schoolroom not far from Honduras' Caribbean coast, 17-year-old Cesar Vicente ${ }^{2}$ carefully recorded his answers in response to a series of questions about his secondary school education. After nearly an hour of concentrated writing, he noted down some of his concluding thoughts: "What they have taught us in SAT is something very important," he explained, "because it helps us to understand and analyze the things that we should change in our lives. ... I think that we as students should be the first to take initiative in reflecting and seeing what are the principal concerns of our community."

While the dedication of Cesar Vicente and his classmates illustrates the powerful potential of youth living in materially poor circumstances, the difficulties facing them are formidable. For decades, expanding access to education has been seen as a primary means for reducing the incidence of poverty and improving living conditions in Central America and other continents and regions around the world (Becker, 1964; Nelson and Phelps, 1996;

\footnotetext{
* Tel.: +25078 8658311.

E-mail address: honeyman2@wisc.edu.

PhD candidate in the Department of Educational Policy Studies, at the University of Wisconsin Madison, United States.

${ }^{1}$ Abbreviations used in this article include: SAT (for the Sistema de Aprendizaje Tutorial, the Tutorial Learning System) and CB (for the Centros Básicos, the conventional public lower secondary schools in Honduras).

${ }^{2}$ In order to protect the privacy of the students participating in this study, all students who are quoted have been given pseudonyms in the form of first and middle names.
}

Psacharopoulos, 1973, 2004). The results, however, have been mixed at best (Pritchett, 2001; Reimers, 2000). Learning advancements in academic areas considered fundamental, such as literacy, mathematics, and the sciences, continue to register profound inequalities between the socially advantaged and their disadvantaged peers. Even relative success in these academic areas, furthermore, is only loosely linked to an improved ability to earn a livelihood after school completion, as testified by the large numbers of unemployed school-educated youth found in many parts of the world. But equally seriously, participation in formal schooling often seems connected to increased individualism and the disintegration of mutually supportive social ties, rather than to their reinforcement and enactment in service of collective advancement. Yet, while schooling is expected to increase the "human capital" of individuals and a great deal of research has explored this topic, its effect on "social capital" or "social solidarity" is rarely a focus of discussion.

The research presented in this article was motivated by the conviction that the strengthening of social solidarity, through the development and reinforcement of an attitude of social responsibility at the individual level, is one of the most fundamental contributions an education system can and should make to the process of participatory social and economic development in a given region. That this educational goal has often been neglected may be due both to disagreement about whether it is a priority, and to the lack of knowledge about how social responsibility can be deliberately cultivated as an integral part of formal educational activities.

Through a case study of the Sistema de Aprendizaje Tutorial, or SAT - an innovative secondary-level education system that has gained a reputation for its ability to promote social responsibility -

0738-0593/\$ - see front matter (c) 2010 Elsevier Ltd. All rights reserved. doi:10.1016/j.ijedudev.2010.02.004 
this article aims to begin filling that latter gap in knowledge. Following a discussion of research activities and methods, I first present a quantitative comparison of survey measures of social responsibility taken from 93 SAT students and 88 other students in conventional Honduran schools, with samples based on the naturally occurring (non-random) presence of one of these two different educational programs in each of nine nearby Honduran communities. This preliminary analysis suggests that students in the SAT program held a significantly greater sense of social responsibility than their peers in conventional schools. I then present an analysis of students' statements about their own educational experiences, in order to identify some of the characteristics of the SAT program that may have led to this difference. Contrasting the SAT approach to developing social responsibility to the more human rights based approach in Honduras' conventional schools, I relate these research findings to learning theory regarding conceptual integration and coherence.

\subsection{Social responsibility and participatory development}

The ability to engage in a participatory process of development - defined, in this article, as people's effort to improve their own quality of life in both its material and social dimensions - is affected by the profound social changes occurring within many rural communities in Central America and in many other regions around the world. On the one hand, the low chances for economic prosperity in rural areas, coupled with the pervasive influence of messages in the media and schools that characterize rural life as somehow intrinsically "backward" or deficient (Borsotti, 1984; Carlson, 2000; Schmelkes, 2000), have resulted in a high rate of migration from rural communities to the cities and even across borders (Breslin, 1987). While the effects of this migration are complex and not wholly negative (Alarcón, 2002), it nevertheless places some serious limitations on the autochthonous advancement of communities in disfavored regions. Particularly, the repeated exodus of the young and able contributes to a growing sense that rural life is something for individuals to escape rather than help improve.

This effect is compounded, on the other hand, by the difficulties in sustaining cooperative or collective action for promoting important community endeavors (Bebbington, 1996). Though a certain subset of individuals in a locality may be gaining increased knowledge, capacity, and access to resources through education and training programs, the benefits from such advancements are often limited to themselves or their close family members. In the context of Honduras, these difficulties were illustrated perhaps most clearly in Smith's (1994) study on Granja Loma Linda, a training farm started by Honduran teacher and farmer Elías Sanchez. Of the difficulties the program faced in promoting a shared process of learning and agricultural advancement, Smith writes:

Farmers in the program already have a platform, based on the respect they have gained from the community for their economic successes, to promote social improvements: schools, education, potable water systems.... They could put their creative thinking to the service of the community. They could share what they have learned. They could work together. And yet, for the most part, they do not... (Smith, 1994, 72-3).

This lack of cooperative effort, of course, is not only found in rural communities or among the materially poorer members of a given society. It is also evident in the mistrust and insecurity that characterize many urban areas and in the relative neglect that privileged groups display towards each other and towards the more socially and economically disadvantaged in innumerable societies around the world.

One way to describe these circumstances is in terms of low "social capital" or "social cohesion." Social capital is a concept that was perhaps made most famous by Robert Putnam's book, Bowling Alone (2000), although its origins lie in the works of such theorists as Alexis de Tocqueville, Emile Durkheim, Max Weber, and others. Michael Woolcock defines social capital as “... a broad term encompassing the norms and networks facilitating collective action for mutual benefit" (Woolcock, 1998, 155). Along with "human capital," social capital has emerged as a point of central concern the literature on economic development. While not all economists agree as to its importance, "[social capital] provides a useful umbrella term for those aspects of societies which, though difficult to measure and incorporate into formal models, are widely thought to be an important determinant of long-run economic success" (Temple, 2001).

While social capital is gaining increasing attention in social and economic development initiatives, many have begun to use the term with an almost exclusive emphasis on its economic meaning. Nan Lin, for example, writes that social capital is “. . . investment in social relations with expected returns in the marketplace" (Lin, $2001,19)$. Some theorists have objected this narrowing of the term, noting that it leaves behind another very important aspect of social norms and networks-the willingness of people to act on behalf of others without the expectation of reward. The term "social cohesion," or "social solidarity," is often used to differentiate this concept from the strictly economic perspective on social capital. While "solidarity" has its own difficulties with clarity and precision (Bayertz, 1999), the Organization for Economic Cooperation and Development defines it as “... co-operation, a sense of social duty and reciprocity not founded on any immediate payback for those contributing to the welfare of others" (OECD, 2001, 59).

Both social capital and social solidarity are commonly seen as qualities that play a crucial supporting role to the process of social and economic development. The "building blocks" of social capital and solidarity can be found at every level, from families and community associations to national and even trans-national institutions (OECD, 45). Yet ultimately their foundations lie in the attitudes and actions of individuals. Speaking of the individual as "rooted within a larger social network," Sheldon Berman emphasizes that "social responsibility" is the personal quality or attitude that supports this broader quality of cohesion, by enabling people to be "... active and responsible members of the larger social and political community” (Berman, 1997, 11-12). Berman's concept of social responsibility focuses on the "... nature of a person's relationship with others and with the larger social and political world" (Berman, 12), and involves “... social and political consciousness, a sense of connectedness, acting on ethical considerations, prosocial behavior, integrity of action, and active participation" (Berman, 14). Adapting Berman's own terminology slightly (Berman, 1990), for the purposes of this study I define social responsibility as "the personal investment in the well-being of others and society as a whole."

Formal education has long been conceived of as a process leading to individual empowerment ${ }^{3}$ and advancement; yet it is also expected to bring about the improvements in collective circumstances usually implied by the term "development". McLaughlin and Davidson (1994) write that "... individual change [can] become a bridge to community solidarity and social change" only when the means for individual empowerment "... motivates

\footnotetext{
3 "Empowerment" is another term that is frequently used with imprecise definitions. For my purposes, I define "empowerment" in terms of gaining an understanding, and a greater ability to actively shape, the forces at work that affect one's life.
} 
Table 1

General Characteristics of the SAT and CB programs.

\begin{tabular}{|c|c|c|}
\hline Characteristic & SAT & $\mathrm{CB}$ \\
\hline Years of study & 6 Years (a full secondary school program). & 3 Years (lower secondary school only). \\
\hline Structure & $\begin{array}{l}\text { The primary elements of the program are a group of students, a tutor, } \\
\text { and the SAT texts (of which each student must have his/her own copy; } \\
\text { often students undertake group income-generating projects in order to } \\
\text { purchase the texts at cost). The number of SAT groups per community } \\
\text { depends on the number of students wanting to study at different levels, } \\
\text { as well as the availability of suitable local residents to be trained as tutors. } \\
\text { No specific complex of buildings is necessary; groups meet wherever } \\
\text { possible and make their own schedule. Field coordinators travel } \\
\text { among communities to assist tutors, who otherwise work independently. }\end{array}$ & $\begin{array}{l}\text { Each grade level has one or two classrooms of students; } \\
\text { teachers are somewhat specialized by subject and move } \\
\text { among classes according to a fixed schedule. There is a } \\
\text { formal school infrastructure with blocks of classrooms, } \\
\text { and an established set of administrators for each school. } \\
\text { Schoolbooks exist, but are primarily used by teachers as } \\
\text { lesson guides, while students often only have notebooks. }\end{array}$ \\
\hline $\begin{array}{l}\text { Teaching-learning } \\
\text { interactions }\end{array}$ & $\begin{array}{l}\text { Students typically sit all together in a circle or in small groups, and read } \\
\text { aloud in turn from their texts, pausing frequently to discuss the } \\
\text { questions posed to them in the readings and exercises. The tutor plays } \\
\text { a guiding role in conversations, and also helps students organize } \\
\text { the practical activities proposed in the texts. }\end{array}$ & $\begin{array}{l}\text { The teacher typically stands at the front of a classroom } \\
\text { full of students who are seated in rows, presenting lessons } \\
\text { using the chalkboard, which students copy into their } \\
\text { notebooks. }\end{array}$ \\
\hline Curricular content & $\begin{array}{l}\text { Each text is integrated around the development of a certain capability, } \\
\text { so that the curriculum is not divided rigidly by academic discipline. } \\
\text { Mathematical, scientific, technological, and language capabilities, } \\
\text { as well as developing abilities in specific forms of service to the } \\
\text { community, are the main focus of the texts. }\end{array}$ & $\begin{array}{l}\text { There is a formal curriculum and textbook for every subject, } \\
\text { divided by conventional academic discipline, such as } \\
\text { the various branches of mathematics, the different } \\
\text { sciences, history, civics, religion, language, etc. }\end{array}$ \\
\hline $\begin{array}{l}\text { Attention to social } \\
\text { responsibility }\end{array}$ & $\begin{array}{l}\text { The SAT texts integrate considerations related to social } \\
\text { responsibility throughout all areas-even those concerned primarily } \\
\text { with mathematics or the sciences. Social responsibility is cultivated } \\
\text { in relation to the human beings in general, rather than in relation } \\
\text { only to the local community or patriotism to the nation. }\end{array}$ & $\begin{array}{l}\text { Issues of social responsibility are mainly focused within the } \\
\text { Civic Education textbooks, which deal explicitly with issues } \\
\text { such as family and community life, governing institutions, } \\
\text { regional and international organizations, human rights, etc. }\end{array}$ \\
\hline
\end{tabular}

people to improve not only their own lives but the lives of others." If educational processes can become more effective at helping young people gain a sense of social responsibility, then they will become a more reliable "bridge" to broad positive economic and social change as well.

\subsection{The Sistema de Aprendizaje Tutorial and its presence in Honduras}

The findings presented in the following sections are based on the perspective that one of the best ways of gaining greater insight into a process is to observe a system that has already achieved some advancement in the desired direction. Accordingly, I set out to study the Sistema de Aprendizaje Tutorial (Tutorial Learning System), a rural education program that offers a rigorous secondary education particularly strong in mathematics and the sciences, yet also has the reputation of successfully cultivating the personal investment in the well-being of others that I refer to above as "social responsibility".

This 6-year secondary education program, known as SAT, was originally designed in the 1970 s by the Foundation for the Application and Teaching of the Sciences (FUNDAEC) in Colombia, specifically to contribute to a process of community development in the rural areas around the city of Cali. SAT has gained international recognition (European Expo 2000 Jury Verdict, and Club of Budapest Change the World-Best Practice Award) for its contributions towards rural social and economic development, in part as a result of its experience of educating students in skills of positive leadership and attitudes of service towards the community. From its initial modest beginnings, SAT has now been implemented in 23 Colombian departments, with over 50,000 graduates and around 40,000 current students (Brief Comments, 2003). Through partnerships with more than 40 other institutions participating in a collaborative network, SAT's reach has also been expanded beyond Colombia-to Brazil, Ecuador, Guatemala, Honduras, and Panama, among other countries (FUNDAEC, 3-4). Preparation for Social Action (PSA), a program recently established by local NGOs with the assistance of FUNDAEC in a number of countries in Africa, South America, and South East Asia and the
Pacific, also uses SAT's materials though without being linked to the countries' formal education systems.

Of all the SAT programs outside of Colombia, Honduras has the most established system, with over 1000 students participating in the departments of Gracias a Dios, Atlántida, and Colón at the time of this research, ${ }^{4}$ and a formal government mandate to pursue national expansion throughout the country's rural areas. When SAT was first introduced in Honduras by an NGO called the Bayán Association, most rural communities on the northern coast had very limited access to secondary education, usually requiring travelling to and boarding in the closest urban center, with all the associated costs in addition to the basic school fees. In these conditions, the SAT program provided a welcome opportunity for students to continue their education closer to home, with its structural innovations making it possible to locally educate the smaller groups of students at each age level typically found in Honduras' rural communities, rather than drawing on a large catchment area as is necessary for the cost structure of conventional secondary schools. SAT was also intended to be much more directly relevant to students' lives than conventional schooling, and envisioned an entirely different role for both student and teacher in the learning process (see Table 1 above for more details).

A few years after SAT began to spread from the department of Gracias a Dios into Atlántida and Colón, the Honduran government decided to establish institutions called "Centro Básico" (or "Basic Center", referred to as CB in this article) in some rural localities to permit students to study the first 3 years of secondary education closer to home. The CBs were constructed along the lines of conventional schools, with a classroom for each grade level, an administrative structure overseeing multiple teachers, and students following the national curriculum through essentially "chalk and talk" teaching strategies. Table 1 presents a comparison of some of the salient aspects of both the SAT and CB programs.

\footnotetext{
${ }^{4}$ The research was originally conducted in 2003.
} 
Although the CB concept brought an opportunity for postprimary education to more rural communities, even these institutions were not available to more than a fraction of rural students; furthermore, the CBs only offered the first 3 years of secondary school compared to SAT's complete 6 year program. Many communities therefore continued to request new SAT groups to be established in their area. This conjunction of neighboring communities hosting one of two different educational systems provided the natural opportunity for comparison on which this study was based.

\section{Research activities and methods}

While a few studies have examined the academic results of SAT (see for example, Pineda et al., 2001), and some other aspects of the program such as its impact on women's empowerment (see Murphy-Graham, 2007, 2008), SAT's reputation for cultivating social responsibility had not been systematically studied before this research. Although ideally a study of program effects would be longitudinal and possibly even involve random selection of students to be assigned to each program, such a design was not practically feasible for a background study such as this one. Instead, the naturally occurring circumstance of students from neighboring rural communities being involved in two different secondary education systems provided an opportunity to at least roughly isolate the effects of participation in a given program on attitudes of social responsibility. Since both programs included efforts to teach topics related to social responsibility, though in different forms (see Table 1), it was possible that students in both programs would display similar levels of social responsibility.

The research was designed to fulfil two linked purposes. First, it was necessary to determine whether there was indeed anything distinctive about the perspective of SAT students regarding social responsibility, or whether instead they reflected essentially the same attitudes as their peers in the CB schools. The quantitative portion of this research was thus framed as a test of the "null hypothesis" that there is effectively no difference between SAT and CB students in the sample on measurements of their attitude of social responsibility. If this null hypothesis could be rejected (i.e. the data demonstrated a statistically significant difference between the two groups of students, holding other explanatory variables constant), and the data also suggested a consistently higher degree of social responsibility among SAT students, then the second purpose for the research would follow: an initial qualitative exploration of how the SAT program might be contributing to a greater development of social responsibility among its students. These two limited objectives are accomplished in the following pages, permitting other researchers to determine whether the subject merits further and more in-depth study.

\subsection{Sample selection and characteristics}

From the two Honduran departments of Atlántida and Colón, ${ }^{5}$ I selected 8 SAT groups from 6 different rural communities, among those lying within $3 \mathrm{~h}$ in either direction of the city of La Ceiba, stretching along the East-West Caribbean coast road network. I deliberately selected these groups in such a way as to represent a wide range in the quality of their experience in the program (based on such factors as the regularity of their tutor's attendance and his or her grasp of the materials and purpose of the program).

\footnotetext{
${ }^{5}$ Though the SAT program existed in three Honduran departments at the time this research began, I excluded the third department (Gracias a Dios) from the study because it was so different culturally and demographically from the rest of the country, with its high percentage of Afro-Caribbean Garífuna inhabitants and even
} lower than average access to conventional secondary schooling.
Table 2

Sample characteristics.

\begin{tabular}{llc}
\hline & CB & SAT \\
\hline Total number of participants & 88 & 93 \\
Distinct classrooms/groups & 6 & 8 \\
Distinct communities & 3 & 6 \\
\% of Students Female & $58.0 \%$ & $53.8 \%$ \\
\% Of students religious & $77.3 \%$ & $73.1 \%$ \\
Min. age & 13 & 13 \\
Max. age & 25 & $35^{\mathrm{a}}$ \\
Mean age & 15.9 & $17.3^{\mathrm{a}}$ \\
\% In level 2 (of 6 years) & $47.7 \%$ & $78.5 \%$ \\
\% In level 3 (of 6 years) & $52.3 \%$ & $21.5 \%$ \\
\hline
\end{tabular}

a This higher mean age for SAT was largely caused by outliers. There were only six SAT students above 25 years old: they were $27,27,30,32,34$, and 35 , respectively.

According to the field coordinators working with the selected groups, three of them had high-quality experiences with their tutors, two middling, and another three had low-quality experiences, when measured against SAT's ideal standards. Though all groups shared in common the same set of SAT materials, I hoped that this variation in the quality of their tutor's guidance would help to provide a fairly balanced picture of the program under what I assumed would be generally heterogeneous implementation conditions around the country-an important point, given that time and resource limitations prevented a truly random selection of groups or students from the entire region where the program was being implemented. ${ }^{6}$

After completing the selection of SAT groups I then selected three additional communities where a Centro Básico was present, each neighboring at least one of the SAT communities. Selected CB communities shared with the SAT communities an agriculturebased livelihood, a Mestizo population, and relatively easy access to a main road despite their rural locations. ${ }^{7}$ SAT and CB student groups selected were studying in either the 2nd or 3rd years of secondary school. Both of these levels were included, in order to be able to get a sufficiently large sample size; 3rd year was the upper limit because the $C B$ program only extended to that level, while $1 \mathrm{st}$ year was excluded because students likely would not have had sufficient time for their attitudes to be affected by either program. A total of 93 SAT students and 88 CB students participated in the study. ${ }^{8}$ Sample characteristics are summarized in Table 2.

\subsection{Data collection}

The basic data for the initial comparative aspect of the research came from an extensive written questionnaire with a set of 26 both closed- and open-ended questions, selected and ordered in such a way as to reduce the possible effect of suggestion bias from preceding questions on important indicators. ${ }^{9}$ Ten of these questions contained items specifically related to the measurement of an attitude of social responsibility, while others gathered

\footnotetext{
${ }^{6}$ Some of the SAT groups in the region were quite far from access roads. These more remote groups would not have provided appropriate comparisons for this study's purposeful sampling approach, as CBs were commonly situated closer to a main road.

${ }^{7}$ Unfortunately, I did not have access to more specific demographic information at this local level, and was not able to independently gather it during the research period. The degree of demographic and economic similarity of these communities thus depends on my personal judgment during research visits, and on that of educational field coordinators working in the region.

${ }^{8}$ Though the full SAT sample was 96 , three SAT students had to be excluded from the analysis because they did not indicate their ages, a key possible explanatory variable.

9 SAT students also answered additional questions that were intended to gather some extra background information, and in some cases would be useful to the Bayán Association for its own internal efforts to improve the program's implementation.
} 
information on a range of other topics not directly related to the focus of the present article, such as students' typical home activities and descriptions of student group dynamics. In analyzing the data on social responsibility, I examined the distribution of responses to each individual question, as well as constructing a Social Responsibility Index that combined all of them into a single measure; details are described further in the Findings section.

As a supplement to this questionnaire data, I also observed 1$2 \mathrm{~h}$ of class time in the majority of the groups, reviewed curricular materials from both programs, and carried out structured interviews with 15 SAT students (randomly selected from within four SAT groups of varying tutor quality $)^{10}$ and three other students (randomly selected from within a fifth group that had initially studied in the SAT program before a CB was established in their community). ${ }^{11}$ I then inductively analyzed both the content of the open-ended survey questions and the interview transcripts, using the software AtlasTI to label and associate together common themes in students' discussion of any aspects of the program connected to their sense of social responsibility. The quantitative data reviewed below provides justification for this qualitative analysis and its focus on SAT students rather than on those from the $\mathrm{CB}$ program, though future research would no doubt benefit from a more in-depth quantitative and qualitative investigation of both programs simultaneously.

\section{Findings}

The following paragraphs present both the quantitative and qualitative findings from the SAT and CB students' questionnaires and interviews.

\subsection{Quantitative findings: differences in social responsibility between SAT and $C B$ students}

The first task of analysis involved establishing whether there was indeed any difference between SAT and CB students on measurements of the attitude of social responsibility. The null hypothesis (that participation in either the SAT or CB program has no distinctive effect on student's sense of social responsibility) would have to be retained if the distribution of answers given by each group was either the same or so similar as to be statistically insignificant. As the data below shows, however, there is a statistically significant difference on the majority of these measures, in all cases indicating a higher degree of social responsibility on the part of the SAT students. When these measures are combined into a single index, and other possible explanatory variables are controlled using OLS multiple regression, the effect of the SAT program still appears positive and statistically significant, indicating that the null hypothesis must be rejected.

The questionnaire items relevant for this section's analysis operationalized social responsibility in three interrelated ways: (1) the level of importance placed by the student on establishing positive and mutually supportive dynamics in interpersonal and group relations, (2) the student's level of interest in helping others and making efforts on behalf of others rather than focusing only on the self, and (3) the scope of the social sphere for whose well-being the student felt actively responsible (e.g. the self, those with close social ties such as family and friends, and those with more distant social ties such as other members of a geographical community).

\footnotetext{
${ }^{10}$ I selected four students from each group, but one of those selected did not appear for his interview.

${ }^{11}$ Again, one of the four originally selected students was not available for the interview.
}

The survey also attempted to investigate students' enactment of social responsibility in several different ways, ${ }^{12}$ although as selfreport measures, these questions may have limited validity. The scope of this study did not make it possible to observe students' relationships and helping activities directly, although this would be an important step for further research. The following paragraphs and tables summarize results from the relevant measures individually, followed by a multiple regression analysis of their combination into a single index.

\subsubsection{Detailed findings: extending social responsibility to greater social spheres}

The survey items relevant for measuring social responsibility included both closed- and open-ended questions. The primary set of closed-ended questions used Likert-type measures to ask students about the importance of certain aspects of their lives. Students assigned a value of "not important", "only a little important", "important", or "very important" to 19 different statements, including a set of four items linked to social responsibility ("having good relations with others", "being generous", "helping my community", and "strengthening the unity of my community"). In a separate set of questions about their studies, students also ranked the relative importance of "helping my community" as compared to other aspects of their education (such as getting good grades, understanding the concepts, etc). Table 3 below summarizes the different degrees of importance placed by students on these first five indicators of social responsibility (labeled SR1-5), as well as their respective $\mathrm{Chi}^{2}$ tests of significance. A few of the question items that were not directly linked to social responsibility are also included for comparison in the latter half of the table.

In the items included for comparison, it is possible to see that the two student groups were nearly identical on questions of the importance of helping their family-already indicating some sense of responsibility extending beyond their own selves. However, differences begin to appear when considering certain personal qualities that are related to social responsibility, such as generosity and the desire to build positive relationships with others. The distinctions are even more pronounced in the two measures that asked students about contributing positively to the community sphere, beyond the family.

These findings were upheld again in students' responses to several open-ended questions, which were included in order to gain a deeper understanding of the way students thought, while running less risk of prompting for socially acceptable answers. To analyze each of these questions, I read multiple times through the responses. On the basis of the types of comments frequently made by students, I constructed a set of typical categories, one or more of which showed a socially responsible attitude. I then transformed these categories into a series of non-exclusive dummy variables for each question, in order to measure the percentage of students who gave each type of socially responsible answer. Table 4 below lists the open-ended questions and the categories of responses that were coded as indicating social responsibility. Two additional response categories not specifically associated with social responsibility are included for comparison.

\footnotetext{
12 One of these questions - asking students to show the number of hours they spent weekly on different activities - proved to be invalid because students did not have a consistent understanding of how to use the chart provided in the survey. Another set of questions asked students whether they had experienced changes in their relationships with family, friends, or neighbors. On this measure, SAT students consistently described more positive and concrete examples of changes than their CB counterparts. However, because of space limitations, this data has not been included here. The only question regarding enactment that has been included, therefore, asked students whether they were in any way helping with a community problem, and if so, what.
} 
Table 3

Likert-type questions, including five items related to social responsibility and others for comparison.

\begin{tabular}{|c|c|c|c|c|c|c|}
\hline Question & $\mathrm{CB} / \mathrm{SAT}$ & $\begin{array}{l}\text { Very } \\
\text { important }\end{array}$ & Important & $\begin{array}{l}\text { A little } \\
\text { important }\end{array}$ & $\begin{array}{l}\text { Not } \\
\text { important }\end{array}$ & $\begin{array}{l}\mathrm{Chi}^{2} \text { test of } \\
\text { significance }\end{array}$ \\
\hline \multirow[t]{2}{*}{ SR1: Having good relations with others } & $\mathrm{CB}$ & $30 \%$ & $52 \%$ & $15 \%$ & $3 \%$ & \multirow[t]{2}{*}{$0.030^{*}$} \\
\hline & SAT & $47 \%$ & $44 \%$ & $9 \%$ & $0 \%$ & \\
\hline \multirow{2}{*}{ SR2: Being generous } & $\mathrm{CB}$ & $33 \%$ & $53 \%$ & $9 \%$ & $5 \%$ & \multirow[t]{2}{*}{0.066} \\
\hline & SAT & $52 \%$ & $36 \%$ & $10 \%$ & $3 \%$ & \\
\hline \multirow[t]{2}{*}{ SR3: Helping my community as an aspect of my life } & $\mathrm{CB}$ & $19 \%$ & $64 \%$ & $15 \%$ & $2 \%$ & \multirow[t]{2}{*}{$0.000^{* * *}$} \\
\hline & SAT & $58 \%$ & $36 \%$ & $5 \%$ & $1 \%$ & \\
\hline \multirow[t]{2}{*}{ SR4: Helping my community as an aspect of my studies } & $\mathrm{CB}$ & $13 \%$ & $21 \%$ & $30 \%$ & $38 \%$ & \multirow[t]{2}{*}{$0.009^{* *}$} \\
\hline & SAT & $19 \%$ & $35 \%$ & $28 \%$ & $17 \%$ & \\
\hline \multirow[t]{2}{*}{ SR5: Strengthening the unity of my community } & $\mathrm{CB}$ & $28 \%$ & $50 \%$ & $17 \%$ & $5 \%$ & \multirow[t]{2}{*}{0.050} \\
\hline & SAT & $45 \%$ & $45 \%$ & $8 \%$ & $2 \%$ & \\
\hline \multirow[t]{2}{*}{ Helping my family } & $\mathrm{CB}$ & $74 \%$ & $23 \%$ & $2 \%$ & $1 \%$ & \multirow[t]{2}{*}{0.653} \\
\hline & SAT & $73 \%$ & $26 \%$ & $1 \%$ & $0 \%$ & \\
\hline \multirow[t]{2}{*}{ Strengthening the unity of my family } & $\mathrm{CB}$ & $63 \%$ & $31 \%$ & $7 \%$ & $0 \%$ & \multirow[t]{2}{*}{0.380} \\
\hline & SAT & $63 \%$ & $31 \%$ & $3 \%$ & $2 \%$ & \\
\hline \multirow[t]{2}{*}{ Having power or authority } & $\mathrm{CB}$ & $9 \%$ & $15 \%$ & $38 \%$ & $39 \%$ & \multirow[t]{2}{*}{0.103} \\
\hline & SAT & $3 \%$ & $13 \%$ & $29 \%$ & $55 \%$ & \\
\hline \multirow[t]{2}{*}{ Studying and learning } & $\mathrm{CB}$ & $75 \%$ & $22 \%$ & $2 \%$ & $1 \%$ & \multirow[t]{2}{*}{0.620} \\
\hline & SAT & $80 \%$ & $17 \%$ & $3 \%$ & $0 \%$ & \\
\hline
\end{tabular}

${ }^{*} \mathrm{Chi}^{2}$ test of statistical significance: $p<0.05$.

${ }^{* *} \mathrm{Chi}^{2}$ test of statistical significance: $p<0.01$.

$\mathrm{Chi}^{2}$ test of statistical significance: $p<0.001$.

Table 4

Open-ended questions and response categories.

\begin{tabular}{|c|c|c|}
\hline Question & Response category & SR indicator \\
\hline $\begin{array}{l}\text { Make a list of two or three people } \\
\text { you admire a lot. Why do you admire them? }\end{array}$ & $\begin{array}{l}\text { I admire X because s/he has a good job or earns a lot of money. } \\
\text { I admire X because s/he helped me or my family in some way. } \\
\text { I admire X because s/he is friendly with others, has positive relations } \\
\text { with other people. } \\
\text { I admire X because s/he helps other people or our community as a } \\
\text { whole. }\end{array}$ & $\begin{array}{l}\text { Comparison } \\
\text { Comparison } \\
\text { SR6 } \\
\text { SR7 }\end{array}$ \\
\hline $\begin{array}{l}\text { In what occupation would you like to work? } \\
\text { Why? What are some other important } \\
\text { goals in your life? }\end{array}$ & $\begin{array}{l}\text { I would like to do X type of work because it will help other people or my } \\
\text { community as a whole; or, Helping other people or members of my } \\
\text { community is an important goal in my life. }\end{array}$ & SR8 \\
\hline $\begin{array}{l}\text { Imagine that you have successfully finished your } \\
\text { university studies. There are some possibilities for } \\
\text { employment in a few organizations in Tegucigalpa... } \\
\text { A few months ago, you offered to help with a big } \\
\text { project in your community that needs the abilities } \\
\text { and knowledge that you could contribute... Would } \\
\text { you try to find employment in Tegucigalpa, yes or no? } \\
\text { Why? Explain your answer. }\end{array}$ & $\begin{array}{l}\text { No, I would not try to find employment in Tegucigalpa, because: } \\
\text { - I made a promise to my community, and I should fulfil that promise first } \\
\text { - I would prefer to stay permanently in my community to help it advance } \\
\text { - What I do in my community will help everyone there, not just me and } \\
\text { my own family. }\end{array}$ & SR9 \\
\hline $\begin{array}{l}\text { Are you currently helping with some problem in your } \\
\text { community? What problem? Why are you helping? } \\
\text { How are you helping? }\end{array}$ & $\begin{array}{l}\text { Yes, I am helping to resolve a problem in my community. (The } \\
\text { percentage of those who gave a specific example of what they } \\
\text { were doing was also measured separately). }\end{array}$ & SR10 \\
\hline
\end{tabular}

a This is an abbreviated version of the hypothetical case given to students, which appeared on the survey prior to any other question related to social responsibility.

Chart 1 displays the results of this analysis, showing that the level of social responsibility indicated by the answers of the SAT and $\mathrm{CB}$ students in each of these five areas was again markedly different.

These findings have noticeably consistent implications across all of the measures: while SAT and CB students are nearly identical in their statements about contributing to well-being of their own family, some differences appear regarding the degree of importance placed on establishing positive dynamics in interpersonal relations. The greatest distinction, however, appears time and time again with regard to the social sphere beyond their familyexpressed in the questionnaire as "vecinos" (neighbors) or as "comunidad" (community). Whether regarding the qualities for which they admired others, their own life goals, their commitment to upholding a promise to their community, or actually giving time and effort to help with a community problem, SAT students on average demonstrated consistently more concern for making a positive contribution to the lives of others. A general pattern has emerged: overall, students in the SAT program seem to hold a greater sense of social responsibility as extending not only to those with whom they already held direct ties, but also to a broader range of people living around them.

\subsubsection{Identifying explanatory variables and their level of significance}

While the preceding analysis gives reason to believe that there is some difference between SAT and CB students, the meaningfulness of this interpretation depends on the assumption that the students' educational program was the primary independent variable determining any difference in the level of social responsibility demonstrated by the different groups. Because this research is not a true experiment involving random assignment to the two programs, I cannot guarantee that this assumption holds; however I did make efforts to choose students from communities that were similar in many respects, as described above. Additionally, there is no evidence that SAT students joined the SAT program because they were more predisposed to socially responsible attitudes: responses to an openended survey question asking students why they decided to study in SAT or CB showed that the vast majority of students who chose to 
Chart 1: Responses to Open Ended Questions

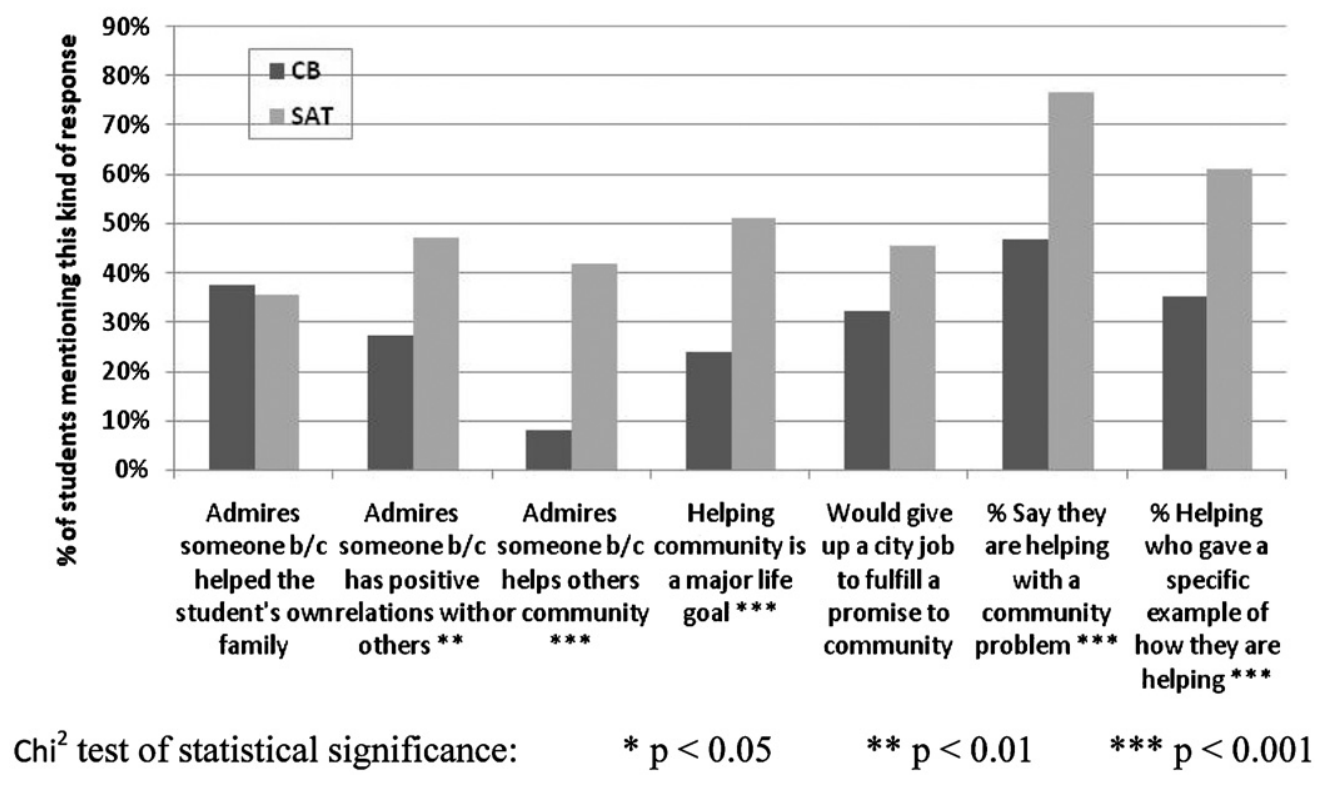

Chart 1. Responses to open-ended questions.

Table 5

OLS multiple regression analysis.

\begin{tabular}{|c|c|c|c|}
\hline Independent variables & Unstandardized coefficients & Standardized coefficients & Significance \\
\hline Program $(\mathrm{SAT}=1)$ & 0.187 & 0.536 & $0.000^{* * *}$ \\
\hline Sex $($ female $=1)$ & 0.008 & 0.024 & 0.721 \\
\hline Religiosity (religious = 1) & 0.025 & 0.061 & 0.360 \\
\hline Age at time of survey & 0.006 & 0.117 & 0.077 \\
\hline Level in secondary school & 0.042 & 0.116 & 0.090 \\
\hline Intercept: 0.23 & $R^{2}: 0.30$ & & \\
\hline$R: 0.55$ & Adjusted $R^{2}: 0.28$ & & \\
\hline
\end{tabular}

Test of statistical significance: ${ }^{* * *} p<0.001$.

study in SAT did so because there were no other options that were affordable or available to them, not because of preference for some known feature of SAT's curriculum.

Beyond the question of generally shared social and economic characteristics and reasons for entering the secondary school program, however, there are specific elements of difference between the student populations that are important to acknowledge. These include gender balance (a slightly higher percentage of women in CB than in SAT), age distribution (slightly older in SAT than in $\mathrm{CB}$ ), and level of religiosity (greater in CB than in SAT); see Table 2 above. Social psychological research indicates a higher likelihood of prosocial attitudes and behavior among women (advantaging the CB sample for greater likelihood of socially responsible attitudes), older ages (advantaging SAT), and religious individuals (again advantaging CB). It is also possible that the student's level in secondary school might have some independent effect on their attitude of social responsibility, if the content regarding social responsibility is more intense in 1 year than another, or if the curriculum's treatment of social responsibilityrelated themes has a cumulative effect (advantaging the $\mathrm{CB}$ sample, which had a higher percentage of students in level 3 ).

In order to test the relative importance of each of these potential explanatory variables, given that the study could not employ experimental controls, the following table presents OLS multiple regression results. The dependent variable for these regressions is a single index, here called the Social Responsibility Index (SRI), constructed from the ten individual measures of social responsibility cited above: importance placed on being generous; having good relationships with others; unity within the community; helping with the development of the community as an aspect of the student's life; helping the community as an aspect of his/her education; admiring someone for his/her ability to establish good relationships and for efforts to help others; helping the community as a career or life goal; willingness to give up a job to fulfil a promise to the community; and reported engagement in practical efforts to help with a community problem. ${ }^{13}$ The SRI is expressed as a fraction of 1 , with 1.00 being the "perfect" score a student would obtain if s/he gave a maximally socially responsible answer on all questions included in the index.

The multiple regression results, taking into account each of the possible explanatory variables listed above, are presented in Table 5. These should be interpreted with the usual note of caution that the SRI may in fact be ordinal and not interval, a common challenge faced in social science uses of this statistical technique.

This table shows that, while holding constant all of the other independent variables, the student's educational program has both

\footnotetext{
13 I also constructed a second index, SRIb, in recognition of the fact that two of the questions - the importance of helping the community as an aspect of the student's education, and taking action to assist with a community problem - might be acting more as measures of the program's direct characteristics, rather than of the student's personal attitude (since the SAT curriculum, for example, leads to specific projects to help with certain common health, environmental, agricultural and educational issues in the region). SRIb thus included only the remaining eight social responsibility measures. However, the separate OLS multiple regression of SRIb showed essentially the same results as for the 10-item SRI, with the result that I have only included the data on the more inclusive SRI here.
} 
the largest and most statistically significant effect on the score obtained on the Social Responsibility Index, with attendance in SAT linked to higher social responsibility. Holding constant other variables, both higher age and higher level in secondary school also appear to be somewhat positively associated with social responsibility as well, though to a lesser extent than participation in SAT. It is possible that there are other unmeasured variables (aside from random variation in individual personality) that could explain further patterns, such as parents' level of social responsibility. However, there is little reason to believe that such measures would vary systematically by educational program. Thus, the null hypothesis must be rejected, and the data strongly suggests that the SAT program has some positive effect on students. development of an attitude of social responsibility.

\subsection{Qualitative findings: elements of the development of social responsibility in $S A T$}

The quantitative findings presented in the previous section suggest that on average, SAT students placed a higher degree of importance on establishing positive and mutually supportive dynamics in interpersonal and group relations, and showed greater interest and commitment to helping and making efforts on behalf of others, particularly in regards to the broader social sphere that includes their neighbors and other members of their geographical community. These differences appeared consistently on both closed- and free-response questions, in questions about both ascribed importance and enactment of the attitude of social responsibility. Multiple regression tests also confirmed that participation in the SAT program is the most significant measured independent variable contributing to these differences.

These findings affirm the relevance of investigating the SAT program further in order to better understand how it may help to cultivate this broader sense of social responsibility. In an additional set of free-answer items on the survey, students described their experiences in the SAT program, the ways that their relationships with friends, family, and neighbors had changed since they began studying in SAT, and other aspects of their studies that they felt had particularly affected their lives. These same questions were asked of CB students in relation to their own education, and provided helpful data for understanding differences between the two programs' educational experiences. To this qualitative data, I added the transcripts from the 15 interviews I conducted with students who had experience in the SAT program, as well as interviews with three students who had been in both the SAT and CB programs at different points. In the analysis of this qualitative information, I first searched for common themes that appeared repeatedly in a large number of students' answers. After sorting these comments using the software AtlasTI, I then reviewed repeatedly all those comments related to a particular theme, working to understand the aspects of their educational experience that students themselves felt were most connected to their development of a sense of social responsibility.

Complemented by a review of the curricula of both the SAT and CB programs, my analysis of SAT students' free-answer responses and interview transcripts led to the identification of five factors as playing important interconnected roles in SAT's apparent effectiveness in cultivating social responsibility: (1) First, the use of a principle of human interconnection as an organizing concept threaded throughout the curriculum created a coherent context for thinking about their relationships with and responsibilities towards others. Next, the program reinforced understanding of that principle and its implications through (2) frequent opportunities for student interaction and discussion and (3) encouraging close study of others' profound reflections on this issue in both poetry and prose. And finally, SAT seemed to encourage a general enthusiasm for acting on this understanding through (4) a consistent linking of theoretical explorations to practical applications in all curricular domains and (5) a focus on continual improvement towards excellence and increasing coherence between principles and actions in one's personal life.

In the following paragraphs I briefly introduce some of the qualitative data that led me to identify these five important factors. Due to space constraints, I have included here only a few remarks from students in relation to each theme; these are typically representative of a much larger selection of comments expressing similar ideas.

\subsubsection{Unity: an overarching principle of human interconnection}

What makes some students more focused than others on contributing positively to the lives of those around them? What makes some notice and admire the efforts they see others making to contribute to their entire community? What makes some say that they would choose to fulfil a promise to help in their rural locality even if that meant giving up a much-coveted opportunity to work in the capital city? The SAT students' comments suggest that one explanation may be the way in which they see their relationships with others, both in their current and in their ideal form.

Throughout this study's field research, and later, in reviewing the data, I noticed that one particular concept - "unidad" - seemed to play a central role in the way many SAT students thought about their relationships with others and the surrounding community. This word (which I have translated as "unity"), and the related term "solidaridad" (solidarity), appear in both the SAT materials and $\mathrm{CB}$ civics texts, and I had used "unidad" as a way of talking about positive group relations in several of the survey questions. Only $17 \%$ of CB students actually mentioned one of these words in their free-response answers, however, making the 70\% of SAT students who wrote about solidarity and unity seem especially remarkable. In interviews, a further 15 of the 18 students with experience in SAT spoke extensively about the concept without any prompting or direction.

Taking the comments of the SAT students as a whole, they consistently linked the concept of "unity" to an array of other positive actions and qualities, many of them integral elements of social responsibility. To them, unity was a principle that implied being attentive to the needs of others and helping them; not fighting, arguing, or gossiping; being humble and having mutual trust with others; ${ }^{14}$ reaching out or connecting with others more; seeing others as intrinsically valuable; recognizing fundamentally shared attributes among people; and thinking of diversity as a natural source of strength in a unified system.

Students appeared to see "unity" as a distinctive way of conceiving of the relationships between people, one that they had rarely encountered before entering SAT. One student wrote, for example, "What the SAT texts teach is to be united, that there should be unity with the whole world, and to be dynamic people who are ready to help others without selfishness or egoism. Outside SAT, one only looks out for oneself." Armando spoke about his understanding of this, reciting a quotation in one of the SAT texts from memory and then explaining it to me phrase by phrase: "There is a quotation that I remember well. . “' O well-beloved ones! The tabernacle of unity hath been raised.' This means, that we are already part of the same whole, that there is no resentment, ${ }^{15}$ that

\footnotetext{
4 The word "confianza" appears frequently in students. comments throughout the surveys and interviews. This word has two different meanings, depending on context. In some circumstances, it translates as "confidence," or "self-confidence." In many other instances, however, it is used to convey a sense of trust, a willingness to confide in someone, or a feeling of close familiarity. I have most often translated the second meaning into the English word "trust" or "mutual trust," but it is important to note that it may hold these other shades of connotation as well.

${ }^{15}$ The actual word he used here is "rancor." However, since this word is not
} commonly used in English, I have replaced here with the word "resentment." 
friendship is going to unite us. And it says, 'regard ye not one another as strangers'-that we should not see others as unfamiliar, but rather as friends or companions. 'Ye are the fruits of one tree, and the leaves of one branch.' That is how we are; we are from Naranjo, ${ }^{16}$ and we should be united, so that we can discover the friendship that there is among us."

Even while the students discussed the many divisions that had to be overcome as part of this process, they did not appear to think of unity in the same way as "uniformity" or "homogeneity". Gloria told me of a lesson in SAT's first mathematics text, for example, explaining: "Here, it talks about various classifications, and that not all are good, because they divide people... For example, color, race, social class... Yes, there are many things, like religion, that also divide-[even though] they should unite us." Later, she continued: "Diversity means ... there is variety, and that always helps to strengthen unity... Every person has capacity, and should make the most of developing [that talent]. Not everyone thinks the same way, sometimes one person likes to do one thing, and another likes to do something different. But everything helps in the end. ..".

Ultimately, the concept seemed to give these students a profound sense of hope, as they saw "unity" as a foundation that, once established, would allow them to achieve many other positive things in their lives. Jerson Gilberto told me a parable from the first book they studied in SAT, a story that described a father who illustrates the concept of unity to his children by telling them to add one twig at a time to a bundle, until their joined strength made them impossible to break. "In unity," Jerson explained, "there are many things that can be achieved-the progress of a community, a town, a country... unity has to be supported, because when there is unity, it is difficult to be defeated."

\subsubsection{Consultation and dialogue}

The concept of unity seems to have provided many of the SAT students with a way of thinking about their connection with others and their responsibilities towards them. Their surprisingly nuanced and profound understanding of the idea of unity, however, did not come automatically. Many students spoke to me about the importance of SAT's emphasis on consultation and dialogue for helping them understand this and many other aspects of their studies.

Dialogue is an integral part of SAT's pedagogy-even the narrative passages of their textbooks frequently pose questions during the exploration of an idea, as if in conversation with the students, and groups usually pause to discuss those questions as they encounter them, before continuing the reading. The texts' exercises also promote a great deal of interaction as students help each other understand new concepts and their implications. One student, Nelson, talked about how SAT encourages its students to ask each other and the tutor questions until they have grasped the meaning of a new topic, contrasting this experience to conventional schools (colegios). “... In the colegios, they don't give the freedom to explain when you doesn't understand something-you doesn't understand like that, because they only explain it one time... But here, they say that if you doesn't understand, you should ask. I tell them that I didn't understand and they go back and explain. This way, you learn a lot, because it gives you more confidence-that one can ask..."

While some of this explanation came from the tutor, often it was the students themselves who would talk together about a subject they were studying until each person had understood. Several students mentioned how this process of arriving at an understanding as a group allowed them to really grasp the meaning of something they were studying and to begin to consider how it applied to their own lives. I asked Sandra why she was able to remember so many of the passages they had learned. She laughed, "It

\footnotetext{
16 Place name has been changed.
}

stays in our minds! Because most often with these quotations. . the ones that we took most seriously, we put them up on the wall, and we explained to each other what it meant. .." Lesli described how this process had helped them to think in new ways about what they were studying: "I think that my opinion changed as a result of entering to study here in SAT ... [but] if we had only read the books and had not talked about them... I would have always had the same opinion, and I wouldn't have changed in anything."

Many students also emphasized how important this discussion was in terms of building their skills of communication, describing their increased confidence in speaking, their greater ability to communicate their own thoughts, and their newly developed willingness to really listen to the perspectives of others, as qualities they developed through the SAT program. Sandra Delores described clearly the impact that this orientation has had on her SAT group. "[In our group]," she explained, "we learned to communicate with one another and to ... begin to understand each one of us a little better. We always have disagreements and all that; it's not that we're perfect. But, no, we always share. We help each other to be able to share ideas among us... I think that this has helped us... Sometimes, a person gets angry, for some reason... or he gets angry with someone and he doesn't want to speak any more. But here in The Power of the Word [it tells us] that one should be friends more than anything. ... so, if I get angry with someone, well, we'll see how to solve the problem, we'll see how we can arrive at a solution." These dynamics were not limited only to interactions within the SAT group-many students wrote or spoke about the positive effects of bringing this kind of dialogue into their relationships with friends, family, and neighbors.

The opportunities for frequent discussion integrated within SAT's methodology therefore seem to have reinforced these students' social responsibility in at least two ways, by helping them to understand the curriculum's fundamental teachings about the interconnections among people, and also by giving them ample opportunities to practice enacting those ideas about social responsibility through more confident and respectful communication with others.

\subsubsection{The role of poetry and quotations}

Throughout my research, another one of the clearest messages I gathered from student after student was the importance of the introductory text, The Power of the Word (El Poder de la Palabra), ${ }^{17}$ which chronicles the story of a group of youth who collaborated to learn about how to promote the progress of their rural village, and who present their ideas and experiences in a community meeting and in a radio program. The main focus of the text is on improving language abilities, but students' favorable impressions of this book went beyond the specific vocabulary and verbal skills that the material taught. Indeed, from the moment I brought out a few of the SAT texts during interviews, nearly every student picked up The Power of the Word and spoke with animation about the verses scattered throughout it, often connecting them to what they had learned about the importance of unity. These verses included poetry from several famous authors, quotations from the writings of the Baháí Faith, and proverbs and fables from various regions of the world. ${ }^{18}$ After mentioning a few examples of such passages,

\footnotetext{
17 This text has been translated from Spanish into English, under the title Drawing on the Power of the Word.

18 These quotations from the Bahá'í Faith, a world religion, appear to be included for the benefit of their insightful content and not for the purpose of emphasizing the Bahá'í Faith itself, which is never mentioned in the book. Caren Rosenthal, of FUNDAEC, explained in answer to a question I posed about these quotations: "[The quotations] are simply there in places where they are needed in order to serve the purpose of more fully investigating whatever subject is being studied... they are used as one source of knowledge in the process of investigating reality...." (Rosenthal, personal communication, March 5, 2004).
} 
sometimes from memory, many students made a comment like Lesli Alvarenga's: "The truth is that for me, in this text, the most important are the messages that it gives us... I mean, these. . quotations. For me, they are the most important because they tell us something, and as we are reading them, and they are entering into our minds, they will cause a change that we wish for."

For Lesli, as for many others, these verses seemed to be set aside as something special, something that caused them to think in a different way than did the other material they were reading. On the one hand, this is perhaps not surprising, considering that The Power of the Word asks students to learn many of these passages by heart as a part of the activities accompanying each lesson. Yet as my interviews continued, and later when I began analyzing them as a whole, it became apparent that there was something to the students' impressions that lay beyond the simple act of memorization. In the subtext of students' answers, I found two additional factors.

First, the students seemed to sense a profound depth of meaning in these quotations, which went beyond the more straightforward text they had read in other places. One such comment came from Gerson Roberto, a young-looking boy who had studied with SAT for 1 year before his community decided to establish a Centro Básico instead. When I handed him a copy of The Power of the Word to see if he remembered it, the change in his bearing was immediately perceptible. Before I had even finished asking him my first general question about the text, he had opened the book directly to a particular quotation he remembered studying and read out loud: "Love thou the children of men and share in their sorrows. Be thou of those who foster peace. Offer thy friendship, be worthy of trust. Be thou a balm to every sore, be thou a medicine for every ill. Bind thou the souls together..." He said, "Here. I still remember this. This really caught my attention. . I remember very well the quotations that we learned."

Has this had any influence in your own life?" I asked. He answered immediately: "Yes. Look, here, it says '. . . Be thou a balm for every sore.' When someone is sad, you should console him. If someone treats us badly, one should advise him to behave well. . [you want] them to see the change in your own life." After he had talked with me about several passages that he remembered vividly, I asked him if there was anything else he wanted to say about the book before moving on to other topics. "This text," he explained, "has really helped me a lot, because it had many of these verses, these poems, that help us in our community, in our families. It had advice for us... and everything, almost all of the text is an illustration for youth, of how we should be... Here, with these books, we would sit, oooeee!, talking about a million things.

Second, beyond this sense of a great depth of meaning, the language of these passages seemed to cause many students to make a connection between them and other influential sources of moral authority in their own lives, especially the Bible. While not every student in SAT is religious, Honduras, like many other Latin American countries, is very much imbued with the culture and teachings of Christianity, particularly Catholicism. Not surprisingly, many of the students made connections between the poems and quotations they encountered in some of their SAT texts, and the lessons about morals and virtues that they had learned through their church and their reading of the Bible. Jerson, for example, recited the following poem to me: "Beautiful faces are they that wear/The light of a pleasant spirit there;/Beautiful hands are they that do/Deeds that are noble, good and true;/Beautiful feet are they that go/ Swiftly to lighten another's woe." Surprised, I asked him whether he really still remembered the verse by heart. "Always!" he answered. "I have always felt that one shouldn't strive just to please oneself, but rather to try to look out for the good of others too. So I really liked this poem... There is a verse in the Bible that says, 'Don't look only to your own good, but also that of others."'
As much as many of these students found a kind of spiritual depth in what they were studying in the SAT texts, they did not seem to directly equate these passages with their experiences of formal religious instruction. I asked one student, Sonia Ayala, whether what she was learning in SAT was the same or different from what her church's youth group taught. "It's different," she answered, "because in the church meetings, they teach us different things than what is taught here. There, they only give us doctrines [doctrinas], and here... here, no, because they teach us truly to share with everyone."

\subsubsection{Purpose and direction: internal coherence and the pursuit of excellence}

Thus far, I have shown how the concept of unity represents an overarching conceptual framework that many SAT students draw upon in their understanding of human society and their own responsibilities towards others. I have also shown that both the quotations included in the texts and the frequent opportunities for discussion throughout the SAT program support the development of students' understanding of the concept of unity, its connection to other ideas they were learning about, and its practical implications. In addition to these three characteristics, students also spoke about two other factors that encouraged them to put that understanding into action.

One of these was the importance of SAT's underlying discourse of purpose and direction. Rather than focusing students' attention exclusively on grades and examinations, though tests were used for certain purposes, the program seemed to approach education as part of a more general process of personal transformation, orienting students in the idea that they would be continually refining their own knowledge and actions in the world as part of striving for excellence. Indeed, one of the first lessons many students mentioned to me when I asked them about what they remembered from past years in SAT was the quotation: "Let each morn be better than its eve and each morrow richer than its yesterday." 19 Although most had learned this phrase over a year and a half earlier, many recited it from memory during the interviews. The prominence of this quotation in many students' minds illustrates a kind of cultural expectation of positive change that seemed to have developed among SAT students, and permeated the perspective many of them had on the progressive nature of their own learning and development.

Many students talked about how their own positive changes, and their own understanding that progress is possible, have influenced others too. Jerson Gilberto talked about his own way of approaching friends and trying to help them with their troubles.

. . with friends, many people have lost their values," he explained. "We have tried not only to talk with them, but to be able to orient them towards something good, so that these values can be restored... We always try to be examples, no? So that they can reflect on this. And to say that truly, they can... all that we need is a little more personal effort."

Perhaps what most surprised me in looking at students' answers was the depth of insight these students had into the profound meaning of personal motivation in the context of this underlying notion of progress. While looking at the text Reinforcement of Primary Education, Nelson Castillo read to me, "'Strive to acquire internal perfections and external perfections alike. They have always been and will always be the fruits of the tree of humanity.' ... This is," he explained, "to always be united, as you

\footnotetext{
19 In Spanish: "Que cada amanecer sea mejor que su noche y cada mañana más rica que su ayer." Some of these quotations come from the Bahá'i Writings and have official English translations, which in this case uses the poetic form "morn" and "eve" rather than "morning" and "evening". Where possible, I have drawn from these official translations rather than translating myself.
} 
Table 6

Contributions to social responsibility.

\begin{tabular}{|c|c|}
\hline Characteristic & Contributions to social responsibility \\
\hline $\begin{array}{l}\text { Organizing } \\
\text { concept: unity }\end{array}$ & $\begin{array}{l}\text { Encourages students to think about and value human } \\
\text { interconnections in a different way. Helps form a } \\
\text { coherent framework shaping their continual } \\
\text { development of the attitude of social responsibility. } \\
\text { Provides a principled guide for the qualities that should } \\
\text { characterize their interactions with others. }\end{array}$ \\
\hline $\begin{array}{l}\text { Poetry and } \\
\text { quotations }\end{array}$ & $\begin{array}{l}\text { Builds and deepens understanding of the organizing } \\
\text { concept of unity, as well as encouraging further } \\
\text { reflection about the purpose and meaning of human } \\
\text { life and the nature of students' relationships others. } \\
\text { Inspires and provides guidance both for initial action } \\
\text { and subsequent refinement of efforts to act in a socially } \\
\text { responsible way. Also provides guidance for positive } \\
\text { and productive discussions. }\end{array}$ \\
\hline Dialogue & $\begin{array}{l}\text { Builds and deepens understanding of the organizing } \\
\text { concept and the ideas contained in the poetry/quotations. } \\
\text { Helps students learn to value diversity of perspectives } \\
\text { and abilities as a source of strength and insight. Enables } \\
\text { continual learning from experience as students discuss } \\
\text { their efforts to enact social responsibility. }\end{array}$ \\
\hline $\begin{array}{l}\text { Practical } \\
\text { application }\end{array}$ & $\begin{array}{l}\text { Builds understanding and deepens the roots of their } \\
\text { growing attitude of social responsibility through efforts } \\
\text { to apply it. Provides direct and concrete opportunities } \\
\text { for practicing social responsibility in the context of } \\
\text { applying many other kinds of knowledge useful for the } \\
\text { well-being of a locality. Helps students realize that } \\
\text { they are capable of promoting positive change. }\end{array}$ \\
\hline $\begin{array}{l}\text { Pursuit of } \\
\text { excellence }\end{array}$ & $\begin{array}{l}\text { Builds a culture of intrinsic motivation among students } \\
\text { to increase the coherence between their principles and } \\
\text { their behavior, to gain greater understanding, and to act } \\
\text { on that understanding in a way that is continually } \\
\text { refined and improved. }\end{array}$ \\
\hline
\end{tabular}

are on the outside, so on the inside too-so that you reflect what you are within. . . Here it says, 'They have always been and will always be the fruits of the tree of humanity.' This is the fruit of a person, that he is always improving, that he reflects everything, that he puts everything into practice."

\subsubsection{Practical application}

The last element that may have been central to SAT students' development of a sense of social responsibility was the continual interaction in their materials between the development of theoretical concepts and their application to certain practical activities. The section presenting the quantitative findings of this study noted a large difference in the percentage of students reporting that they were helping with a community problem. One reason may be that an integral element of many SAT texts is a "practice" that encourages the SAT students to directly apply what they are learning to common problems found in rural areas, often as a group. ${ }^{20}$ For example, as part of a review of arithmetic and an introduction to algebra, SAT students were learning some of the basics of demography; in another text they were learning about certain concepts in biology related to common health problems. That second text encouraged the students to employ the two bodies of knowledge together to carry out some surveys and home visits regarding neighboring families' health problems. Other examples of SAT practices included students using their own language abilities to start small study groups to promote adult or child literacy, and addressing certain issues related to agricultural practices and

\footnotetext{
${ }^{20}$ See footnote 13 for an explanation of how I dealt with this issue in the Social
} Responsibility Index. the environment. The CB curriculum, in contrast, was not so practically oriented.

This aspect of SAT was the final major factor emphasized by the students I interviewed as they tried to explain why their participation in SAT had led to changes in their attitudes and actions related to social responsibility. Beyond the particular projects students are involved in, the SAT students seemed to have a general willingness to experiment with the application of new ideas, perhaps because even when they study something that is not immediately applied, the students have a background expectation that what they learn can (and should) be put into practice. Just as Nelson explained above, “... This is the fruit of a person: that he is always improving, that he reflects everything, that he puts everything into practice," many other students emphasized that the process of learning does not end with mastery of the theory of something; that theory must also be applied. One student wrote in his survey, "I knew that thinking of others and helping those who need it was good, but I almost never put it into practice. Now that I have begun studying in SAT, I have learned that it is good to put this in practice, and these days I try to help with what I can."

Students also frequently emphasized how their studies and the accompanying practices had equipped them with new levels of knowledge and skill, so that they felt more capable of being of assistance to others. A large number of students wrote about how the practices they had carried out through SAT had given them understanding to draw on where they felt they had none to contribute before. One student wrote, "Before, I couldn't help others because I didn't have much knowledge, but now that I have some understanding and experience, I can help others by teaching them a little of what I know." In addition to building capacity, these efforts also appear to have led to tangible improvements in their relationships with others, as was evident in the comparably large percentage of SAT students who gave positive examples of how their relationships with their neighbors had changed since they entered SAT, compared to a much smaller number giving similar examples in $\mathrm{CB}^{21}$

Finally, one of the results of SAT's focus on connecting knowledge to practical activities is students' realization that their efforts truly can have an impact on their surrounding community. As quoted at the beginning of this article, Cesar Vicente wrote: "Before, I had very little interest in the problems of the community. Now I think that we, as students, should be the first to take initiative in reflecting and seeing what are the principal concerns of our community." Jerson commented, "In this program, [we see] that truthfully, the progress of this community depends on me, depends on all the members. One just has to begin; then the others can join too..."

In Table 6, I summarize how these different characteristics of SAT appeared to interact with each other to reinforce the development of socially responsible attitudes and actions.

\section{Discussion: conceptual integration and coherence}

The complete picture illustrated by the data suggests that the development of something as deeply rooted as "personal investment in the well-being of others" requires a high level of coherence in an educational program, integrating many different learning approaches towards the same central purpose, and drawing that thread throughout all curricular areas. The comments of students

\footnotetext{
${ }^{21}$ For reasons of space, the full analysis of these four open-ended survey questions (regarding changes in the student's relationships with friends, family, and neighbors, as well as changes in his/her perspective on contributing to the community), has not been included here, although there was again a noticeable difference between SAT and CB students, and their responses were helpful in identifying each of the five factors explored in this qualitative section.
} 
in the SAT program indicate that the development of social responsibility is supported when students are encouraged to think deeply about profound passages encouraging socially responsible behavior, have the opportunity to discuss together the ideas behind an orientation of concern towards others, and put these ideas into practice through meaningful and relevant prosocial activities. And beyond these factors was the centrally important issue of motivation - rather than focusing energy around shortterm and extrinsic factors such as grades and exams (though these are present in minimal form), SAT appears to cultivate a sense of intrinsic motivation, helping students develop a personal desire to continually advance closer towards excellence in all areas of their lives - including in their treatment of others.

I saw from students' comments, however, that even the interconnection of these four elements did not alone form the foundation for developing a sense of social responsibility. Indeed, enveloping each of these aspects within a broader framework and providing a structure of meaning and integration was the concept of "unity," an idea that appeared again and again in students' explanations of how their thinking and actions had changed. The SAT students wrote and spoke about the significance that this idea held for them in a way that seems strongly connected to theories of learning that emphasize the importance of conceptual integration within any curriculum. One educator, Lynn Erickson, describes such integration in terms of using a "conceptual lens" to move beyond mere presentation of facts and disconnected ideas in the context of teaching standard curricular subjects:

A conceptual lens (focus concept) forces thinking to an integration level. Students see patterns and connections at a conceptual level as they relate the topic to the broader study framed by the lens. Without a conceptual lens, a topic of study remains at a lower cognitive level, and students seek to memorize the facts related to the topic. The focus concept facilitates and requires deep understanding, and it allows for the transfer of knowledge (Erickson, 2002, 75).

Although discussions of conceptual integration have typically focused on domains such as mathematics and the sciences, the current research suggests that similar learning processes may also apply to social and moral issues such as learning about social responsibility. SAT students' comments about unity suggest that in the SAT program, this concept of human interconnection functions as a kind of conceptual lens or focus concept. By extension, SAT seems to illustrate the profound potential of an educational approach that helps students grasp the fundamental principles on which human relations could be based, and then integrates other considerations around that idea.

The point about the concept of "unity" serving as a vehicle for conceptual integration deserves some further discussion, as it also highlights a key difference between SAT's approach and that of other programs that attempt to cultivate civic behavior, including CB. The work of psychologist David Ausubel is useful in this regard. Ausubel advocated a specific strategy for assisting students in integrating new information into their existing understanding, helping to make learning more relevant and meaningful. He called his tool the advance organizer, explaining: "In order to function effectively for a variety of learners, each with a somewhat idiosyncratic cognitive structure, and to furnish or modify anchoring ideas at a superordinate level, organizers are presented at a higher level of abstraction, generality, and inclusiveness than the new material to be learned" (Ausubel, 2000, 11, emphasis in the original).

Ausubel suggested that the advance organizers used in the educational environment consist of "the more general and inclusive ideas of a discipline" (Ausubel, 1968, 148). This gives some direction to those teaching in fields that already employ an array of integrating concepts, from geometry and biology to literature to the social sciences. Yet when it comes to education about one's actions in the social world (rather than merely studying society as a phenomenon), the mandate becomes less clear. What are the organizing principles that underlie ethical action in the social world? Perhaps the organizing concept could be love, or care-as suggested by Nell Noddings (2002). Or perhaps, as Kohlberg's moral development theory suggests, justice is the only concern that "... takes on the character of a principle, that is, becomes something that is obligatory, categorical, and takes precedence over other considerations..." (Kohlberg, 1971, 65). More likely, any successful effort to cultivate social responsibility should make use of both of these principles, and many more.

This research on SAT students suggests that, in addition to principles of thought and action (which include love, justice, and care), students may need to draw on a fundamental conception of the nature of the relationship among human beings as they develop their understanding of the meaning and importance of "personal investment in the well-being of others." One could perceive humans as fundamentally separate entities who come together only by happenstance or necessity, but not for any enduring common purpose. Or, one could see human society as a chosen contract of association marked by a struggle for balance between individual rights and social obligation. The SAT program in Honduras draws upon yet another fundamental perspective on human relations-the conception that human beings are intrinsically connected to one another, and form part of an organic whole that must become unified if it is to grow and prosper.

Specifically, SAT students are first introduced to the concept of unity through the metaphor of the human body: Just as the human body has diverse organs and systems working together to sustain life, an early SAT text explains, so do the many individuals and societies that compose humanity need to establish a balance of functioning in harmony with one another. A character in the book's story briefly emphasizes the meaning of this interconnection in the context of the metaphor of a single organism working to sustain itself and grow: "When one part hurts, it affects the whole. Likewise, since all the parts work together with the same purpose, what they achieve is to the benefit of all" (Fundación Ruhi, 2000, 13). Though the metaphor it draws on may seem similar to certain ideas in the structural-functionalist school of thought, the two perspectives are not the same. In SAT, the collaborative functioning of the parts of a healthy and balanced human body is not a model for how our world or any one society currently is, but is rather an indication of the kinds of conditions of reciprocity, collaborative diversity, and unified effort that would need to be established for human society to become healthy.

In this way, the text introduces unity as a fundamental principle for the human being's role in relation to all others in the surrounding world, with human society itself presented as a single organism. From the beginning, this concept is associated with an intimate connection to others, in such a way that harm done even to one human being is perceived as afflicting the entire body of humankind. As a result, each person is exhorted to be concerned for the well-being of others and to work towards the betterment of the whole. Throughout their later lessons, this concept of unity is continually deepened and refined. The students have multiple opportunities to discuss the causes of division between individuals and groups and to begin to think about the roots of animosity and neglect as something controlled by humans and therefore able to be rectified. The texts also develop the idea that, while unity does imply some level of fundamental similarity among human beings, its strength depends on the sharing of diverse talents and perspectives and not on uniformity. And through projects which develop in complexity from tree-planting 
and community presentations to working on health issues with neighbors, to a sustained effort to promote literacy, the students begin to grasp the meaning of being of assistance to others in the context of a principle that is founded in reciprocity and dignity.

Thus, whether intentionally or not, SAT's presentation of the principle of unity appears to fulfil Ausubel's criteria for an "advance organizer." First, it seems to successfully bridge the idea to concepts that many of the students are already familiar with, such as the basic operation of the human body, the benefits and strengths of diversity within an agricultural or ecological system, and also - through the language of the poetry and quotations - to another potent source of guidance in many students' lives, the Bible's call to "love one's neighbor as oneself." On the other side, this overarching concept of human unity provides a conceptual framework that helps students to understand the interrelationships between many of the other qualities they study, such as generosity, justice, love, honesty, and others. Unlike many "character education" programs, students learn about these qualities not in a disconnected way, but rather through an overarching framework that shows their interconnection and meaning within the context of the broader goal of establishing unified relations. That conceptual framework, as it is continually developed throughout the educational program, can help students integrate other discrete concepts of human relations within a coherent whole, and can therefore assist them in transferring the understanding they gain in one context to new situations and relationships.

It is useful to contrast these characteristics of SAT's approach with those found in the $\mathrm{CB}$ curriculum. If there is any broad concept about the human being and society that runs thematically through the Centro Básico materials, it is the idea of the inalienable rights of the human being-perhaps the most prevalent conceptual framework for human relations in the world today. Just a few months into their first year at the Centro Básico, students are introduced to this concept with the following passage:

What are human rights? They are the rights that all people have simply from the fact of their existence, and which should be respected by the State, its authorities, and each one of us. The basic principle of human rights is the dignity of the human being. Life in community imposes on us, as persons, respect of the rights of others: each person has the obligation to permit others to live in an equally dignified manner. Human rights apply to everyone without exception, solely for the fact of membership in the human family (de Cerrato et al., 2002, 36).

At each grade level, the $C B$ civics textbook then goes on to develop students' understanding of human rights, introducing rights of the child, human rights in the family, the rights of women, and more. The texts also explore such fundamental ideas as freedom and human dignity.

Several important distinctions between the SAT and CB materials arise when considering specifically the different conceptual frameworks the two programs begin to develop in their students. First is the degree to which SAT's conceptual framework implies a connection (rather than just rights and obligations) among human beings. In a review of several studies that have investigated the lives of social activists and "moral exemplars" (most notably: Jennings, 1992; Colby and Damon, 1992; Oliner and Oliner, 1988; Hoehn, 1983), Sheldon Berman is able to draw some conclusions about the qualities that commonly characterize those who will go out of their way to help others. One of the primary characteristics was a certain perspective on identity that allowed the activists to see others' lives in connection with their own. Berman writes, "[socially responsible people] experience a sense of connectedness and interdependence with others. The boundaries of their identity are not drawn tightly around themselves... Others and the world as a whole are part of the self" (Berman, 1997, 13). He later reiterates this point, referring to a study of individuals who protected Jews during the Holocaust, where Oliner and Oliner write that their subjects. “...ego boundaries were sufficiently broadened so that other people were experienced as part of the self" (Oliner \& Oliner, 1983, 183).

In contrast to the sense of connection that is cultivated within SAT, the CB civics texts seem to present the individual as essentially independent, brought into reciprocal relations with others only as a result of the necessities of social life, i.e.: "life in community imposes on us, as persons, respect of the rights of others..." The connotation of this passage is that human associations require a certain degree of compromise of our personal freedom, in order to allow society to function without conflict. In the SAT materials, on the other hand, students learn that human beings actually gain their strength and their capacity for joy and progress from their ability to work and live together. Whereas the $\mathrm{CB}$ materials begin with the conception of the individual as the primary unit, with a responsibility to allow others to maintain their own individual freedom within society, the SAT materials place the individual in the context of a whole, clearly stating that, although there is independent action and diversity among human beings, we are also connected to each order within a greater system, with the result that the conditions of one member exert an impact on all others.

This is not to say that the CB texts completely neglect the idea of society as involving reciprocal interconnection among its members. Indeed, the civics materials address the concept of solidarity several times over the years. In the middle of the second civics text, for example, the materials read:

Solidarity is a virtue of the citizen, but at the same time it is a responsibility and a necessity. Solidarity implies commitment and assistance to one another, conscious of a true unity. The success of each person and of the whole community is intimately linked to the success of the national community... it is necessary to associate ourselves in order to achieve success and prosperity... (de Cerrato and de Suazo, 2003, 41).

Yet even in this passage, and in many others like it, the initial perspective of human association is presented as a necessity, and not as a fundamental state of interconnection. Ultimately, the call for solidarity appeals back to the notion of individual success, justifying national (not necessarily universally human) solidarity as a means to that more isolated end.

The second primary distinction between the concepts of human relations as presented by SAT and CB involves the degree to which they call for proactive action. Looking again at the CB student's first exposure to the concept of human rights, the overall sense is one of noninterference, not action towards a particular goal. The passage states that human rights "should be respected," and that "life in community imposes on us. . the obligation to permit others to live in an equally dignified manner." Some of the first phrases studied by the SAT students stand in sharp contrast to this largely passive orientation of the $\mathrm{CB}$ materials. In a quotation cited previously, for example, taken from near the beginning of The Power of the Word, students are called to act in a very different way: "Love thou the children of men and share in their sorrows. Be thou of those who foster peace. Offer thy friendship, be worthy of trust. Be thou a balm to every sore, be thou a medicine for every ill. Bind thou the souls together..." The emphasized words in these quotations illustrate that, whereas CB students seem to be learning from a conceptual framework that emphasizes only the fundamental duty not to deprive others of their rights, SAT asks its students from the beginning to actively reach out and strive to improve the lives of 
those around them. This distinction between the two curricula is further reinforced through their different emphases on practical activities: while the $C B$ students may occasionally have the opportunity to perform discrete acts of community service (such as cleaning up garbage around the school grounds), SAT's sustained projects integrated as part of the learning experience seem to reinforce the tendency towards action to a much greater extent.

Thus, a conceptual framework that provides students with some means for understanding the interconnections and interdependency that exist within human society seems fundamental in helping students see that their actions have importance in the lives of others. By helping students see others, in Berman's words, "as part of the self," this characteristic makes students aware of the profound ways in which human society can progress through their own personal efforts to pay attention to the well-being of others. Furthermore, this research suggests that no matter how welldeveloped a concept may be in a student's mind, it may never lead to action unless the principle itself incorporates a proactive perspective on the individual's role in relation to others. This combination of students increasing their understanding of their interconnection with others, and learning that positive change requires that individuals put their principles into action, seems to provide a strong foundation for developing social responsibility, that "personal investment in the well-being of others" that can be a bridge to positive social change.

\section{Conclusion}

The preceding pages have presented an initial study of the differences between SAT and CB students on certain measures of social responsibility, as well as a preliminary analysis of the characteristics of the SAT program that may have led to the development of a stronger sense of social responsibility among many of its students. There are a number of ways in which future research might explore these issues in greater depth.

First, this study was somewhat limited in terms of its quantitative methodology, without a truly random sampling strategy, and with a fairly small overall sample size. With regards to the comparison of SAT and CB students specifically, the initial findings of this research may be tested through a more extensive study in the same Honduran context, this time with random sampling from the larger student population, or a more systematic approach to matching "treatment" and "control" groups. Alternatively, using the present study simply to frame some of the relevant questions for investigation, further research may be undertaken on a larger scale in relation to educational efforts intended to cultivate social responsibility in many other contexts, whether focusing on the implementation of SAT itself in other countries, or on other educational systems entirely.

Second, this study was also limited in terms of the depth of its qualitative observations. In particular, future research could give more attention to observing the actual classroom interactions of students, their activities outside of their studies, their relationships with others and their efforts to make positive contributions to others' lives. A longitudinal approach would also permit deeper understanding of the processes that are occurring. One such research design might follow first-year students beginning with their entry into each one of the two programs, observing how their ideas and attitudes develop and possibly diverge in response to their different educational experiences and other factors in their lives. Another such approach might follow students after they have graduated from each educational program, in order to see to what extent they put some of these ideas into practice over time.

This article began with the claim that the strengthening of social solidarity, through the development and reinforcement of an attitude of social responsibility at the individual level, is one of the most fundamental contributions an education system can and should make to the process of participatory social and economic development in a given region. Not all will agree with this assertion, but at the very least, the research presented in the preceding pages should give some further insight into how education systems - if we wish them to do so - can motivate students to use their developing understanding and knowledge not simply for the purpose of individual escape from poverty, but towards a process of collective advancement.

\section{References}

Alarcón, R., 2002. The development of the hometown associations in the United States and the use of social remittances in Mexico. In: Garza, R., Lowell, B. (Eds.), Sending Money Home: Hispanic Remittances and Community Development. Rowman and Littlefield Publishers, Lanham, MD, pp. 101-124.

Ausubel, D., 1968. Educational Psychology: A Cognitive View. Holt, Rinehart and Winston, Inc., New York

Ausubel, D., 2000. The Acquisition and Retention of Knowledge: A Cognitive View. Kluwer Academic Publishers, Boston.

Bayertz, K. (Ed.), 1999. Solidarity. Kluwer Academic Publishers, Boston.

Bebbington, A., 1996. Rural development: policies, programmes and actors. In: Preston, D. (Ed.), Latin American Development: Geographical Perspectives. Longman Singapore Publishers, Singapore, pp. 116-145.

Becker, G.S., 1964. Human Capital. University of Chicago Press, Chicago.

Berman, S., 1990. The real ropes course: the development of social consciousness. ESR Journal 1, 1-18 Cambridge, MA: Educators for Social Responsibility.

Berman, S., 1997. Children's Social Consciousness and the Development of Social Responsibility. State University of New York Press, Albany, New York.

Borsotti, C., 1984. Sociedad Rural, Educación y Escuela en América Latina. Editorial Kapelusz, Argentina.

Breslin, P., 1987. Development and Dignity: Grassroots Development and the InterAmerican Foundation. Inter-American Foundation, Rosslyn, VA.

Brief Comments About the Tutorial Learning System (SAT). Document received in email communication from Sarah Makoski Hatami, February 6, 2003. No publication information available.

Carlson, B., 2000. Achieving Educational Quality: What Schools Teach Us. United Nations Publication, Santiago.

de Cerrato, P., de Suazo, R., de Pineda, Y., 2002. Educación Cívica: Primer Curso. Honduras.

de Cerrato, P., de Suazo, R., 2003. Educación Cívica: Segundo Curso. Honduras.

Colby, A., Damon, W., 1992. Some Do Care. The Free Press, New York.

Erickson, L., 2002. Concept-Based Curriculum and Instruction: Teaching Beyond the Facts. Corwin Press, Thousand Oaks, California.

Fundación, Ruhi., 2000. Poder de la Palabra. Royal Palm Beach. Development Learning Press, Florida.

FUNDAEC: Institutional History, pp. 3-4. Document received in email communication from Sarah Makoski Hatami, April 19, 2003. No publication information available.

Hoehn, R., 1983. Up From Apathy: A Study of Moral and Social Involvement. Abington, Nashville, TN.

Jennings, T. Self-in-Connection as a Component of Human-Rights Advocacy. Unpublished manuscript, 1992.

Kohlberg, L., 1971. Stages of moral development as a basis for moral education. In: Beck, C., Crittenden, B., Sullivan, E. (Eds.), Moral Education: Interdisciplinary Approaches. Newman Press, New York.

Lin, N., 2001. Social Capital: A Theory of Social Structure and Action. Cambridge University Press, New York.

McLaughlin, C., Davidson, G., 1994. Spiritual Politics: Changing the World from the Inside Out. Ballantine, New York.

Murphy-Graham, E., 2008. Opening the Black Box: Women's Empowerment and Innovative Secondary Education in Honduras. Gender and Education 20 (1), 31 50.

Murphy-Graham, E., 2007. Promoting Participation in Public Life through Secondary Education: Evidence from Honduras. Prospects 37 (1), 95-111.

Nelson, R.R., Phelps, E., 1996. Investment in humans, technology diffusion and economic growth. American Economic Review 56 (2), 69-75.

Noddings, N., 2002. Educating Moral People: A Caring Alternative to Character Education. Teachers College Press, New York.

OECD, 2001. The Well-Being of Nations: The Role of Human and Social Capital. Organization for Economic Cooperation and Development, Paris.

Oliner, S., Oliner, P., 1988. The Altruistic Personality. The Free Press, New York

Pineda, G., Urtecho, J., Dooki, S., 2001. Informe: del 13 al 18 de mayo de 2001. Comisión Evaluadora del SAT, Honduras.

Pritchett, L., 2001. Where has all the education gone? The World Bank Economic Review 15 (3), 367

Putnam, R., 2000. Bowling Alone: The Collapse and Revival of American Community. Simon and Schuster, New York

Reimers, F. (Ed.), 2000. Unequal Schools, Unequal Chances: the Challenges to Equal Opportunity in the Americas. Harvard University Press, Cambridge, MA.

Rosenthal, C. Personal communication, March 5, 2004

Psacharopoulos, G., 1973. Returns to Education: An International Comparison. Jossey-Bass, San Francisco. 
Psacharopoulos, G.P., Patrinos, H.A., 2004. Returns to investment in education: a further update. Education Economics 12 (2), 111-134.

Schmelkes, S., 2000. Education and Indian peoples in Mexico: an example of policy failure. In: Riemers, F. (Ed.), Unequal Schools, Unequal Chances. Harvard University Press, Cambridge, pp. 319-333.

Smith, K., 1994. The Human Farm: A Tale of Changing Lives and Changing Lands. Kumarian Press, West Hartford, CT.
Temple, J., 2001. Growth effects of education and social capital in the OECD. In: Helliwel, J.F. (Ed.), The Contribution of Human and Social Capital to Sustained Economic Growth and Well-Being: International Symposium Report. Human Resources Development Canada and OECD.

Woolcock, M., 1998. Social Capital and Economic Development: Toward a Theoretical Synthesis and Policy Framework. Theory and Society 27 (2), $151-208$. 